University of Nebraska - Lincoln

DigitalCommons@University of Nebraska - Lincoln

2010

\title{
Is Economics Coursework, or Majoring in Economics, Associated with Different Civic Behaviors?
}

\author{
Sam Allgood \\ University of Nebraska-Lincoln, SALLGOOD1@UNL.EDU \\ William Bosshardt \\ Florida Atlantic University, wbosshar@fau.edu \\ Wilbert van der Klaauw \\ Federal Reserve Bank of New York, wilbert.vanderklaauw@ny.frb.org \\ Michael Watts \\ Purdue University - Main Campus, mwatts@purdue.edu
}

Follow this and additional works at: https://digitalcommons.unl.edu/econfacpub

Part of the Economics Commons

Allgood, Sam; Bosshardt, William; van der Klaauw, Wilbert; and Watts, Michael, "Is Economics Coursework, or Majoring in Economics, Associated with Different Civic Behaviors?" (2010). Economics Department Faculty Publications. 67.

https://digitalcommons.unl.edu/econfacpub/67

This Article is brought to you for free and open access by the Economics Department at DigitalCommons@University of Nebraska - Lincoln. It has been accepted for inclusion in Economics Department Faculty Publications by an authorized administrator of DigitalCommons@University of Nebraska - Lincoln. 


\title{
Federal Reserve Bank of New York Staff Reports
}

\section{Is Economics Coursework, or Majoring in Economics, Associated with Different Civic Behaviors?}

\author{
Sam Allgood \\ William Bosshardt \\ Wilbert van der Klaauw \\ Michael Watts
}

Staff Report no. 450

May 2010

This paper presents preliminary findings and is being distributed to economists and other interested readers solely to stimulate discussion and elicit comments. The views expressed in this paper are those of the authors and are not necessarily reflective of views the Federal Reserve Bank of New York or the Federal Reserve System. Any errors or omissions are the responsibility of the authors. 


\title{
Is Economics Coursework, or Majoring in Economics, Associated with Different Civic Behaviors?
}

Sam Allgood, William Bosshardt, Wilbert van der Klaauw, and Michael Watts

Federal Reserve Bank of New York Staff Reports, no. 450

May 2010

JEL classification: A22, A13, D71

\begin{abstract}
Studies regularly link levels of educational attainment to civic behavior and attitudes, but only a few investigate the role played by specific coursework. Using data collected from students who attended one of four public universities in our study, we investigate the relationship between economics coursework and civic behavior after graduation. Drawing from large samples of students in economics, business, or general majors, we compare responses across the three groups and by the number of undergraduate economics courses completed. We find that undergraduate coursework in economics is strongly associated with political party affiliation and with donations to candidates or parties, but not with the decision to vote or not vote. Nor is studying economics correlated with the likelihood (or intensity of) volunteerism. While we find that the civic behavior of economics majors and business majors is similar, it appears that business majors are less likely than general majors to engage in time-consuming behaviors such as voting and volunteering. Finally, we extend earlier studies that address the link between economics coursework and attitudes on public policy issues, finding that graduates who studied more economics usually reported attitudes closer to those expressed in national surveys of U.S. economists. Interestingly, we find the public policy attitudes of business majors to be more like those of general majors than of economics majors.
\end{abstract}

Key words: economics training, civic behaviors

\footnotetext{
Allgood: University of Nebraska-Lincoln (e-mail: sallgood@unlnotes.unl.edu). Bosshardt: Florida Atlantic University (e-mail: wbosshar@fau.edu). van der Klaauw: Federal Reserve Bank of New York (e-mail: wilbert.vanderklaauw@ny.frb.org). Watts: Purdue University (e-mail: mwatts@purdue.edu). The authors thank the board of the Calvin K. Kazanjian Economics Foundation for the grant that made this work possible and the Committee for Economic Education of the American Economic Association for bringing them together to write the proposal, as described in Salemi et al. (2001). April Fidler provided important assistance in project coordination, administration, and data entry. Georg Schaur worked extensively with data organization and preliminary tabulations. The views expressed in this paper are those of the authors and do not necessarily reflect the position of the Federal Reserve Bank of New York or the Federal Reserve System.
} 


\section{Is Economics Coursework, or Majoring in Economics, Associated with Different Civic Behaviors?}

\section{Introduction}

Studies of voting behavior and civic participation typically include measures for the level of education attainment (Ashenfelter and Kelley 1975; Matsusaka and Palda 1999; Kan and Yang 2001; Dee 2004) Dee (2005) further claims that the type of education matters, reporting that adults who attended Catholic schools are more likely to participate in civic activities such as voting. Other researchers have investigated whether economics and business students are more likely to engage in free riding or other self-interested behavior (Meier and Frey 2004; Marwell and Ames 1981), which could decrease civic participation. We extend this body of research by investigating the relationship between majoring in economics, business, or other subjects, and the number of economics courses completed, to survey responses dealing with several kinds of post-graduation civic behaviors and with attitudes held on seven public policy issues. Our sample is drawn from graduates who attended one of four large public universities in 1976, 1986, or 1996.

A general role of education - presumably including education in economics - is to develop an appreciation for a country's history and civic institutions (Dee 2005), although Acemoglu et al. (2005) offer evidence that education is not essential to the success of democratic government. Earlier research by economists suggested a link between the level of education and

participation in U.S. elections (Ashenfelter and Kelley 1975). Milligan, Moretti, and Oreopoulos (2004) found a significant relationship between levels of education and voting behavior in the United States but not in the United Kingdom, perhaps reflecting differences in U.S. voter registration requirements that establish barriers to participation. 
Education may also influence the decision to donate to political candidates and the decision to volunteer time. Vaillancourt (1994) argues that, in theory, the effect of education on volunteerism is ambiguous because the higher wages associated with more education increase the cost of volunteering, but volunteering may be career enhancing or a method for adding to one’s human capital. Empirically, Vallaincourt (1994), Freeman (1997), and Hayghes (1991) report a positive relationship between the amount of education and volunteering, while Gibson (2001) finds a negative relationship. In a general review of the empirical literature, Galston (2003, p. 32) concludes: “Civic knowledge promotes political participation.”

Some economists have argued that the paradigm presented in most economics courses and textbooks encourages students to see people as self-centered individualists and to behave that way themselves (Marwell and Ames 1981), making them less likely to vote or participate in other civic and public activities. Early public choice models of rational ignorance and apathy suggested that the benefits of voting are less than the costs because a single vote is unlikely to affect election outcomes. Studying those ideas and other examples of self-interested behavior in economics classes might therefore decrease voter turnout and other forms of civic participation. Frey and Meier (2003), however, argued that much of the evidence on these questions relied on experimental results, and did not explain "real world" choices. Using data on voluntary contributions by students to two different social funds at the University of Zurich, they found evidence of self-selection, where economics majors were slightly less likely to contribute than other students even before taking economics courses at the university. The difference in contributions decreased, but not significantly, after they had taken economics courses. In a later study, Meier and Frey (2004) concluded that contribution patterns by business majors also revealed a selection effect, with no significant changes as students completed more coursework. 
Recent public choice models and studies address why people may vote even if they know their votes will not change election outcomes, or why and how they may decide to participate in other kinds of civic and altruistic behaviors. For example, models of expressive voting (Breenan and Hamlin 1998) posit that many people view their votes for candidates or political parties as signals of support for a wide range of political agendas and public policies. Elections serve as periodic referendums on these issues, and many people may feel that it is important and satisfying to have their views represented in those election results. From this perspective voting is like a fan cheering for a team at a sporting event, even if they know their cheering has little or no chance of affecting the outcome of the game. ${ }^{1}$

Blinder and Krueger (2004) analyzed survey data and concluded that individuals' selfreported ideological positions are the single most important determinant of public opinion on economic policy issues. They also found that these opinions influence people's decisions to join a political party, vote, donate money to a political candidate, or volunteer their time. Similarly, Kan and Yang (2001) found that a person's self-reported ideological stance is an important predictor of voting behavior. Other studies link educational attainment to attitudes and ideology. For example, Dee (2004) finds that the amount of education is positively related to support for free speech. And a few earlier studies link individuals' attitudes on public policy issues to their levels of training in economics (Allgood and Walstad 1999; Becker, Walstad, and Watts 1994). In summary, then, studying economics may be related to decisions people make about which candidates and policies to support or oppose either because the coursework in economics

\footnotetext{
${ }^{1}$ See Aldrich (1993) for a discussion of rational voter models. Matsusaka and Palda (1999) view the evidence of their model as supportive of rational voting models and counter to "psycho/sociological approaches (p. 431)." See Conover and Feldman (1986) for early work comparing the role of emotion versus cognition in voter turnout.
} 
changed their understanding or attitudes on some issues and policies, or because people with different ideas on the policies tend to self-select into or away from taking economics courses. ${ }^{2}$

In this paper we use a unique data set of survey responses from over 2,000 graduates who attended one of four large public universities in 1976, 1986, or 1996. We first consider the relationship between studying economics and several different kinds of civic behavior, including joining (or not) a political party; joining a particular political party; voting in the most recent presidential, state, or local election; donating money to political parties or political campaigns; and volunteering time to work (without pay) for other individuals or groups (not limited to political candidates or organizations). We analyze the relationship between these outcomes and both the number of economics classes a person has taken and, in separate estimations, the graduates' choice to major in economics, business, or another field. We include controls for a number of personal background variables found to affect civic behavior in earlier studies (for example, Ashenfelter and Kelley 1975, Matsusak and Palda 1999, Dee 2004, and Acemoglu et al. 2005), including income, a summary measure of the student's academic ability/performance, and whether or not the person went on to earn a graduate degree. The inclusion of the latter covariates will provide insight into the channel through which economics course taking is related with various outcomes, to gauge the extent to which they are captured by income and wealth differences.

To briefly preview our results, those who took more economics classes or who majored in economics or business were more likely to be members of the Republican party and less likely to join the Democratic party. Those findings hold even after controlling for the higher salary,

\footnotetext{
${ }^{2}$ Walstad (1987), Soper and Walstad (1988), Walstad and Soper (1989), and Beron (1990) offer evidence of a recursive relationship between students' levels of economic understanding and their attitudes on economic issues, with changes in understanding leading to changes in attitudes but changes in attitudes not leading to changes in levels of understanding.
} 
higher equity in real estate holdings, and earning a graduate degree. Neither the number of economics classes taken nor majoring in economics are related to the decision to vote in the 2000 presidential election, or in the most recent state or local elections.

Without controlling for salary, the value of real estate holdings, and graduate degrees earned, we found that with a higher number of economics classes taken increased the likelihood that a person had donated money to a political party or campaign. After controlling for those variables, the marginal effect of taking economics courses on the likelihood to donate is reduced by a third. Neither volunteering nor the number of hours volunteered is related to studying or majoring in economics; but business majors are less likely to volunteer, and when they do they donate fewer hours.

Following previous research on the relationship between studying economics and attitudes on public policy issues (Allgood and Walstad 1999; Becker, Walstad, and Watts 1994), we drew several items on public policy issues from a survey of 464 American Ph.D. economists Alston et al. (1992). Becker, Walstad, and Watts (1994) sent a survey of 28 items to national samples of economic educators, secondary economics teachers, secondary [social studies] teachers not specializing in economics, and journalists, and found that the responses of economic educators and economics teachers were closer to responses of economists in the Alston et.al. study than the responses of other teachers and journalists. Allgood and Walstad (1999) gave the same 28 -item survey to a group of 32 high school teachers taking a specialized masters program in teaching economics. At the beginning of the program teacher responses to the survey were more like those of journalists than economists, but by the end of the program their responses were more like those of economists. 
Here, we asked our sample of college graduates for their opinions on seven policy issues. For example, respondents were asked to agree, generally agree, or disagree with the statement “Tariffs and import quotas usually reduce general economic welfare." Alston et al. (1992) reported that 71 percent of economists agreed or generally agreed with this statement. In our sample 43 percent of all of the graduates responding agreed or generally agreed, but that rose to 59 percent for the economics majors. In probit regressions for each of the seven statements, for all but two of the seven items we find a statistically significant relationship between the number of economics courses completed, or majoring in economics, and the likelihood that a person agreed or generally agreed with a statement. On most of the items, graduates who took more economics courses, or majored in economics, gave responses that were more similar to responses by the national sample of Ph.D. economists.

\section{The Data and Descriptive Statistics}

\section{II.A. Survey Procedures and Response Rates}

Our survey was mailed in January 2003 to over 25,000 graduates from four public universities: Florida Atlantic (FAU), Nebraska-Lincoln, North Carolina (UNC), and Purdue. ${ }^{3}$ In addition to the three time cohorts mentioned earlier - those who attended the universities in 1976, 1986 or 1996 - there were three subgroups based on the final majors listed on graduates' transcripts, which we classified as economics, business, or general (anything other than economics and business majors). Business majors include any majors originating in business schools except economics.

For each annual cohort we sampled up to 1,000 students from each of the three different groups of majors at each of the four schools. A random sample of 1,000 students was drawn if a

\footnotetext{
${ }^{3}$ We obtained mailing addresses from the alumni associations at each school, so only a small number (less than 1 percent) of those in our sample did not graduate.
} 
school-year cohort for a given major at a school was larger than 1,000. That was usually the case for the general majors, and often the case for business majors. It was never the case for economics majors, so surveys were mailed to all of the economics majors enrolled in these years. In addition to questions about civic behavior and economic attitudes, the survey included questions dealing with background information on the respondents, questions on the graduates' impressions about their undergraduate coursework in economics and other fields, and a series of questions on labor market and personal finance decisions, which are reported in earlier papers. ${ }^{4}$

Of the 25,292 surveys mailed, 1,313 were returned because of invalid addresses. We received 2,165 completed surveys, for an overall response rate of 9.0 percent (excluding surveys returned with bad addresses). Response rates varied by school (ranging from 5.8 to 11.4 percent) and by major (13.1 percent for the economics majors and about 8.5 percent for business and general majors). The response rate for the 1996 cohort was 10.0 percent, for the 1986 cohort 8.3 percent, and for the 1976 cohort 8.8 percent. ${ }^{5}$ In Allgood et al. (forthcoming), analysis is provided to show that the effects of non-response bias are likely to be negligible, or at least very small.

\section{II.B. Trancript Data and Procedures}

Transcript data were obtained from registrars' offices at the four universities, providing basic demographic information including gender and race, as well as information on students' overall GPA, semester GPAs, economics courses taken, and grades in economics courses.

\footnotetext{
${ }^{4}$ Allgood et al. (2004) provides more information on the survey and findings on perceptions of undergraduate experience with economics courses and instructors, compared to other subjects. Analysis of responses related to labor market experiences and personal financial decisions is presented in Allgood et al. (forthcoming).

${ }^{5}$ Our response rate was predictably low, in part because some of those we surveyed graduated up to two decades earlier, and most were not economics majors. Moreover, no payment was offered to complete the survey, our survey form was long, and several items dealt with very personal information. Compared to similar surveys, then, our response rate does not seem out of line. For example, Frey and Meier (2003) administered a short, online survey to current students at the University of Zurich, with a response rate of 18 percent.
} 
Electronic transcript information was available for the vast majority of survey recipients at all four universities for the 1986 and 1996 cohorts. For the 1976 cohort, however, electronic transcript information was only available at two institutions. At the other two schools we collected transcript information from copies of printed records for every business and general major who returned a survey. In addition, we collected transcript data on 100 randomly selected business and general majors who did not return a survey. We obtained transcript information for all economics majors. For the entire mailing sample, transcript information was available for 23,127 former students, including all but six of the survey respondents.

Not surprisingly, transcripts at the four schools from these three decades recorded different information. Some schools did not provide scores on college entrance exams, and some provided little or no pre-matriculation data (such as high school GPA). As a result, because we pool data from the four schools we can not use information that predates a graduate's enrollment at one of the universities.

\section{II.C. Descriptive Statistics}

Table 1 provides the number of observations and means for all variables included in our analysis. The first section of the table reports means for the entire sample, with and without weights to control for our sampling method. ${ }^{6}$ All but five variables are binary variables with only means reported. For the five continuous variables standard deviations are shown in parentheses, below the means. NormalizedGPA represents an alternative measure of the individual's overall performance in college courses and serves as a proxy of the individual's

\footnotetext{
${ }^{6}$ The sample weight for each cohort-school-major combination is defined as the ratio of the group's share in the student population in each college in 1976, 1986 or 1996 (proxied by the total number of degrees awarded within 4 years of each date), divided by their share in the total sample of potential respondents (the share in the sample of individuals to whom we mailed questionnaires and for whom we obtained transcript data).
} 
overall ability, as defined below. We also present unweighted means for each of our three groups of majors. Our discussion for the full sample will focus on the weighted means.

The first ten variables are respondent's self-reported measures of civic behavior. Almost one-fourth of our cohort-adjusted population are not members of a political party, 39 percent are Republicans, 35 percent are Democrats, and less than 1 percent are members of either the Libertarian (12 persons) or the Reform (1 person) parties. For the sub-group who belong to one of the two major parties, 53 percent are Republicans and 47 percent are Democrats. In 2000, Democrats made up 35 percent of respondents to a national survey by the Pew Research Center (2008), and Republicans 35 percent. Compared to the business and general majors in our sample, economics majors are more likely to be a member of a political party. Economics and business majors are more likely than the general majors to be Republicans. That contrasts with the self-identified political affiliation of American economists: Klein and Stern (2007) surveyed 264 members of the American Economic Association and reported that 23 percent were Republican and 58 percent Democrats.

Over 90 percent of the cohort-weighted sample reported voting in the 2000 presidential election (President), a higher proportion than reported voting in many studies with wider populations. The Census Bureau (Jamieson, et al., 2002) reports that $75.4 \%$ of those with bachelors' degrees voted in the 2000 presidential election. Our sample is more consistent with Milligan, Moretti, and Oreopoulos (2004), who report that 84 percent of college graduates voted. Business students were the least likely to vote in the Presidential election, with general majors most likely - but the differences are not large.

We also asked if the graduates had voted in the most recent state and local elections. Voting rates decreased as the scale of the election became smaller. For the state-level election 
there is even less variation across majors, but in local elections general majors were about 7 percentage points more likely to have voted than business and economics majors.

One-third of our cohort-weighted sample reported that they had, at some time in their life, donated money to a political candidate or political party (DonateMoney). About sixty percent of the population of graduates studies here did some volunteer work (Volunteer). On average, the cohort-weighted sample of respondents engaged in a little over 2.75 hours of volunteer work per week, but the median time donated for the full sample was only one hour. Among only those who volunteered the average was about 4.5 hours per week. General majors were more likely to volunteer, and to volunteer more hours. Milligan, Moretti, and Oreopoulos (2004) reported that only 25 percent of their national sample reported doing any "work on community issues," but their sample included people who did not graduate from or attend college.

The next set of variables listed in Table 1 describes the undergraduate education experience of our sample. The average student in our sample took almost two economics courses, not counting any courses re-taken (\#EconCourses). About 22 percent took no economics classes. On average, economics majors took nine courses, business majors took four, and general majors took one. Three percent of the weighted sample were economics majors (Economics), 15 percent business majors (Business), and the remainder were in other majors (General). The mean cumulative GPA for respondents is about 3.1 (median 3.12), with very little variation across the three groups of majors.

In an attempt to overcome potential ability biases in our estimations, where individuals with higher ability may have a different disposition or motivation for participating in civic behavior, while also self-selecting into different majors, or taking more or fewer economics courses, we control for the individual's overall performance in college courses. Cumulative 
GPA may not be an appropriate measure of ability due to differential grading practices across course fields, universities, and time cohorts (Johnson, 2003). For example, the average GPA of those in our 1996 cohorts is 3.20 versus 3.00 for the other two cohorts, and the difference is statistically different at the 1 percent level. We therefore measure each student's performance relative to all other students in the same course or subject by regressing, separately for each university, all individual student course grades on course subject dummies ${ }^{7}$, course level (whether upper level course), year dummies, and individual fixed effects. The NormalizedGPA variable reported in Table 1 represents the estimated individual fixed effects from these regressions. ${ }^{8}$

In Table 1 we also report cohort, school, and basic demographic data for respondents. The weighted sample is almost equally split between the three time cohorts. General majors have equal representation across cohorts, but only 20 percent of economics majors are from the first cohort, and only 25 percent of business majors are in the second cohort. UNC has the highest representation in our sample, and FAU the smallest. Slightly more than half of the sample is female, and about three percent is black. Females are under-represented in the economics major, which is consistent with national patterns. For example, the $24 \%$ of economics majors in our sample for the period from 1976, 1986, and 1996 compares with an estimate of 31\% for bachelor's degrees awarded in 2008 and most recent years (Siegfried 2009 and earlier annual reports), based on annual surveys conducted by the American Economic Association since $1992 .{ }^{9}$

\footnotetext{
${ }^{7}$ We differentiated courses both within and across general subject fields, resulting in 50 different course subjects.

${ }^{8}$ NormalizedGPA is hard to interpret because we have taken out the major and college specific mean. Consequently, comparing the average fixed effects across majors is meaningless.

${ }^{9}$ The share of female majors in economics probably rose gradually over most of the 1976-19996 period, although it has leveled off over the past few years even as the share of all BA/BS degrees going to females continues to rise.
} 
LiveTogether is a binary variable, set at one if the respondent was living with a spouse or significant other, and zero otherwise. Approximately $70 \%$ of the cohort-weighted sample lived with someone, and the average respondent in our sample had one child at the time they completed the survey. The geographic area of residency of our sample largely reflects the locations of the school a respondent attended: half of the sample lived in the south and just over a third lived in the Midwest. ${ }^{10}$

Our survey also included several questions related to personal assets and income. For the issues of most concern in this paper, home ownership may be viewed as how invested a person is in their community; the variable Rent was entered as one if the person rents rather than owns their residence. We also have other measures of wealth and income. Wealth is proxied by real estate equity - our survey asked: "If you sold all of the real estate you own, including the land and house where you live if you own that property, and then paid off any money you owe on all of that property, how much money would you receive?" Responses were categorical: less than $\$ 25,000, \$ 25,001-\$ 50,000, \$ 50,001-\$ 100,000, \$ 100,001-\$ 250,000$, and greater than $\$ 250,000$. Here these categories are grouped into the three dummy variables reported in Table 1, with the omitted group indicating a value less than $\$ 50,000$. Annual income is proxied using responses to the question: "What was your individual (not family) wage or salary income in 2001, before paying taxes?" Respondents could choose from 14 categorical responses, which are here aggregated into the three dummy variables shown in Table 1 (with responses of less than $\$ 30,000$ the omitted category). Economics majors have the largest percentage of respondents in the highest salary group.

Finally, a large proportion of those in our cohort-weighted sample had completed graduate degrees: six percent an MBA, six percent a law degree, and 4.5 percent a Ph.D. An

\footnotetext{
${ }^{10}$ Region of the country was determined based on the state used for mailing surveys.
} 
additional 30 percent completed some other advanced degree (such as a master's degree other than an MBA). By design, our sample had completed more higher education than the general population samples reported in most previous studies. For example, only sixteen percent of Blinder and Krueger's (2004) sample had completed four years of college, and only ten percent had pursued any kind of graduate education. In our sample a bachelors degree is the highest degree obtained for two-thirds of business majors, which is the highest proportion among the three groups of majors.

\section{Estimation Procedures}

In this section we describe the estimation procedures for evaluating the relationship between studying economics and different forms of civic behavior, and with respondents' attitudes on various economic policy issues. All estimations are done using sampling weights, and include a large number of control variables. For each dependent variable we present estimates from models featuring two different sets of control variables. The first set includes two time cohort and three university dummies, binary variables for gender and race, NormalizedGPA, regional indicators of current residence, a binary variable to show a respondent's marital/significant other status, and a count variable indicating the number of children. The second regression includes an extended set of controls adding rental or home ownership, real estate equity, annual salary, and highest academic degree. ${ }^{11}$ By comparing estimates from both specifications we are able to evaluate the extent to which differences across majors or economics course-taking can be explained by associated differences in income, wealth and postgraduate education. To keep sample sizes as large as possible we convert missing values (with shares of missing values reported in parentheses here) for NormalizedGPA ( 0.9 percent),

\footnotetext{
${ }^{11}$ To the extent that our approach for controlling for ability bias may not completely address the potential endogeneity of our measures of economics training, caution should be used in interpreting the estimated relationships as being necessarily causal .
} 
Rental and Equity (3.9 percent), Number of children (3.2 percent), LiveTogether (1.3 percent), and Advanced Degrees (1 percent) to zero and then include for each a dummy variable equal to one if the variable had a missing observation. The dummy variables for missing observations are not reported in the tables, but were close to the impact of these variables evaluated at their nonmissing mean values.

All regression tables include two panels: Panel A reports the marginal effects for explanatory variables using \#EconCourses as one explanatory variable; in Panel B we replace \#EconCourses with two dummy variables identifying Economics and Business majors, using General majors as the omitted comparison group. The signs and significance for other explanatory variables were not altered by this change in specification, and so are not reported in Panel B. Instead, in Panel B we report the results for two statistical tests: the first tests the null hypothesis that the marginal effect of the economics major equals the marginal effect of the business major (Economics - Business=0); the second tests the null hypothesis that the two marginal effects are simultaneously equal to zero $($ Economics $=$ Business $=0)$. The statistics reported are the $\chi^{2}$ with the $\mathrm{p}$-value in parentheses.

\section{$\underline{\text { III-A. Results on Economics Coursework and Majors and Civic Behavior }}$}

Table 2 reports the marginal effects of two sets of estimations of a multinomial logit model where the three choices are no party membership, Democrat, and Republican. The first set of estimates includes our smaller set of independent variables. The second set adds explanatory variables to control for attainment of graduate degrees, annual salary, and the market value of real estate ownership and equity. The estimated coefficients for the \#EconCourses variable in Panel A are the same across these two specifications, which implies that across this 
group of graduates the relationship between \#EconCourses and party affiliation decisions are not driven by the attainment of advanced degrees, salary, or real estate ownership or equity.

The number of economics courses completed by the graduates of these four schools significantly decreases the likelihood that a person does not join a political party and the likelihood of joining the Democratic party, while the number of economics courses is positively related to the likelihood of joining the Republican party. For example, taking five economics courses is associated with an eight percent decrease in the likelihood of joining the Democratic party and more than a 10 percent higher chance of joining the Republican party. These marginal effects are large relative to the unconditional means reported in Table 1. For example, approximately 40 percent of respondents report being members of the Republican party, so a 10 percentage point increase for 5 economics courses represents a 25 percent increase.

The estimates in Panel B, which replace hours of coursework in economics with binary variables showing our three groups of majors (economics, business and all other fields) indicate that relative to general majors, economics majors are respectively about 5 and 8 percent less likely to join a party and be a member of the Democratic party, and 10 percent more likely to join the Republican party. After controlling for income, real estate ownership and wealth, and highest degree attained, economics majors are less likely to be Democrats, but the marginal effect is no longer statistically different from zero. Again, when compared with the unconditional means, the marginal effects of the choice of major variables indicate that the latter are economically relevant. However, economics majors remain more likely to join the Republican party. Business majors do not differ from general majors in their propensity to join a political party, but they are less likely to be Democrats and more likely to be Republicans. The chi-squared test of a statistical difference between the two marginal effects for economics and 
business majors fails to reject the null hypothesis that the marginal effects are equal. That is, there is no evidence that economics and business majors differ in their likelihood of joining a party or in their likelihood to join a given party. The second $\chi^{2}$ is a test of the joint significance of the two major variables. Choice of major is not statistically related to the decision to join the Democratic party, but is significant for joining the Republican party. Recent national survey evidence has shown a relationship between a person's level of education and party membership (Pew Research Center 2003), but our findings suggest that the field of education as well as the level is related to party affiliation.

Results on decisions to vote (or not) in elections are presented in Table 3. The \#EconCourses variable is statistically unrelated to the decision to vote in the most recent presidential, state, or local election. In Panel B, the variable for the economics major is also insignificant across all six specifications. Depending on the specification, business majors were 3 to 4 percent less likely to have voted in the 2000 Presidential election than general majors. Ignoring real estate ownership and equity, salary, and highest degree, business majors are about 5 percent less likely to vote in the most recent local election, but the marginal effect of Business is reduced by half and statistically insignificant with the additional control variables. Business majors differed from both economics and general majors in their voting behavior. Specifically, they were less likely to have voted in the 2000 presidential election than economics majors. ${ }^{12}$ In general terms, the major classifications were usually significant in predicting the likelihood of voting in the presidential election, but not in the most recent state and local elections.

Table 4 provides estimates for two other forms of civic participation, donating money to political candidates or causes, and volunteering (not just for political activities) without pay. The

\footnotetext{
12 Galston (2001) reported that political knowledge is related to voter turnout, and Milligan, Moretti, and Oreopoulos (2004) found that the likelihood of voting in the U.S. is positively related to the level of education.
} 
likelihood of donating money to political candidates or causes is positively associated with the number of economics courses completed, with the expanded specification in Panel A showing that about a third of that relationship is attributable to differences in income, real estate ownership and wealth, and attaining a graduate degree. The marginal effect is fairly large given that only a third of the sample donated, and a student taking 5 economics courses is 5 percentage points less likely to donate. Results in Panel B indicate that the decision to major in economics, business, or other subjects is not significantly correlated with the decision to make political donations.

The decision to volunteer is statistically unrelated to the number of economic courses completed, and economics majors are not significantly more or less likely to volunteer than general majors. Business majors are less likely to volunteer than general majors by 6 to 8 percentage points. ${ }^{13}$ There is no statistically significant difference between economics and business majors in the likelihood to volunteer, but the choice of major is a significant predictor of volunteerism, with business majors less likely to volunteer than general majors. Similar results hold in the tobit regressions for number of hours volunteered. The binary variable for the business major has the same sign and about the same significance level after including controls for real estate ownership and wealth and salary, which suggests that the lower rate of volunteering is not simply because these graduates face a higher opportunity cost for their time. Furthermore, the differences are substantial if one considers that three-fifths of the sample does some type of volunteering and business majors are 10 percent less likely to volunteer, or that business majors volunteer almost one hour less per week while the sample average is 2.75 hours.

\footnotetext{
${ }^{13}$ Freeman (1994) finds a positive relationship between the level of education and volunteering, but Gibson (2001) finds a negative relationship.
} 
Some interesting results emerge from the other control variables in Tables 2 - 4. Relative to males, female graduates are significantly more likely to join a political party, more likely to join the Democrat party, less likely to donate money to political candidates or causes, more likely to volunteer, and to volunteer more hours. Comparing coefficients and significance levels on the Female variable before and after adding the additional controls, as we just did for the business major variable, shows that the additional controls for income, real estate ownership and equity, and advanced degrees leads to large drops in the gender-related differences on voting behavior, but only to small drops in the party affiliation and donation outcomes, and little or no change in the volunteerism differences. Blacks are significantly more likely (by over 50 percentage points) to join the Democratic party. Blacks are not more likely to volunteer than whites, but they do volunteer more hours.

Many of our measures of civic behavior are strongly related to the number of children a graduate has. Specifically, those with more children are more likely to join a political party (especially the Republican party), more likely to vote, more likely to volunteer, and to volunteer more hours. Living with a significant other is not statistically related to party membership, but those cohabitating are more likely to vote.

Our results are similar to those reported by Kan and Yang (2001) using a sample of about 2,000 voters in the 1988 presidential election, even though only 20 percent of their sample had a college degree. ${ }^{14}$ For example, they found that race and gender did not affect the likelihood that somebody voted, but blacks and females were less likely to vote for the Republican candidate.

We find no statistically significant differences across Census regions in our regressions, except for a slightly higher tendency in the West to vote for President in the 2000 elections, and

\footnotetext{
${ }^{14}$ Their data is from the 1988 National Election Study, which used a nationally representative sample of voting age Americans.
} 
a slightly lower tendency in that region to volunteer. A comparison across cohorts shows older cohorts to be much more likely than the 1996 cohort to have joined a political party, to have joined the Democrat party, to have voted in the 2000 election, and to have donated money to a candidate and to have volunteered, even after controlling for their higher income and real estate equity levels. The cohort effects may capture age effects. That is, those in older cohorts have more years to have experienced joining a political party or volunteering. Of course, this argument does not apply to voting in the 2000 Presidential election since that is a one time opportunity independent of age. It is worth emphasizing that while the marginal effect of many of these control variables suggest that they have an important role in explaining civic behavior in our sample, the marginal effects of our economics courses and choice of major variables are typically larger in magnitude when they are statistically significant.

\section{III.B. Results on Economics Coursework and Majors and Attitudes on Public Policy Issues}

Alston et al. (1992) asked 464 U.S. economists with a Ph.D. to indicate whether they agreed, generally agreed, or disagreed with 40 statements on public policy issues. Despite public opinion and media statements to the contrary, they reported a relatively high degree of consensus among economists.

Our survey included seven policy statements to which respondents could agree, generally agree, or disagree, with six of the items taken directly from the Alston et al. (1992) survey. Our analysis differs from the earlier papers that extended the Alston et al. survey to populations of non-PhD. economists, discussed earlier, in several important ways. Most importantly, we have direct measures of how much coursework in economics our respondents have taken. However, for many of those in our sample it was more than 20 years since their last economics course. That was also true for some of the respondents in the Becker, Walstad, and Watts (1994) study, 
but not in the Allgood and Walstad (1999) small sample (32) of precollege teachers who were completing a master's program in teaching economics.

Table 5 lists the seven items on public policy issues and shows the unweighted and weighted responses for our full sample. The last column in the Table shows the responses of PhD economists for six of the items, as reported in Alston et al. (1992). Except for the statement on government deficits, the fraction of our sample that disagrees with each of the policy statements is statistically different from the fraction of economists who disagreed with these statements. For example, in our cohort-weighted sample, 78 percent agreed or generally agreed with the claim that tariffs and quotas reduce economic welfare, whereas 93 percent of the economists held that view.

We find substantial variation across the three groups of majors in their views on these statements. Economics majors are much more likely to agree or generally agree with the statements on Tariffs and Minimum Wage, and they are much less likely to agree or generally agree with the statements on Income Distribution, Trade Deficits, and Oil Prices. There is less difference between business and general majors than there is between economics and general majors. $^{15}$

We estimate (weighted) probit regressions to see if studying or majoring in economics is related to attitudes on economic issues, setting the dependent variable equal to one if a respondent agreed or generally agreed with the statement, and zero if the respondent disagreed with the statement. Table 6 reports these estimates, using the same format used in Tables 2-4. The first thing to note is that these estimates are almost completely unaffected by the inclusion of

15 Blinder and Krueger (2004) report opinions of a nationally representative sample of households, with more variation in education, income, and region of the country than our sample. They report on several survey items that address similar policy issues, including the minimum wage and the federal deficit, where responses are similar to those we report here.. 
the variables for completion of advanced degrees, real estate ownership and equity, and salary. Most of the dummy variables for these characteristics are not significant, and their inclusion has no influence on the sign or significance of the \#EconCourses or Economics majors variables, and only small effects on the Business majors variable. That suggests that for our sample attitudes on economic issues are not driven by salary and wealth, and more importantly that any linkage between studying economics and attitudes is not simply a proxy for differences in salary, equity, or differences in educational attainment.

The number of economics courses completed is significant for five of the seven economic attitude items, but not with the items on government deficits and smaller government. Those who completed more economics courses were more likely to agree that tariffs reduce economic welfare and less likely to think that trade deficits adversely affect the economy. The more economics courses taken the less likely respondents were to believe that government should regulate oil prices, and the more likely they were to believe that the minimum wage increases unemployment. Finally, the more economics courses taken the less likely respondents were to believe that the distribution of income should be more equal. In sum, those taking more economics classes favored less regulation or government intervention affecting prices for specific goods and services, including wages and salaries. But there was notably less association between economics coursework and beliefs about the optimal size of government or government deficits - perhaps because ideology plays an even greater role on those questions, as suggested by Blinder and Krueger (2004).

The marginal effect for the economics majors (shown in Panel B) corresponds closely with the Panel A results for \#EconCourses. Economics majors differ significantly from general majors on the same five issues for which the variable \#EconCourses is statistically significant. 
Business majors differ from general majors on four issues: Trade Deficits, Government Deficits, Minimum Wage, and Distribution. Economics and Business majors differ on 3 or 4 of the issues: Tariffs, Trade Deficits, and Oil Prices - with the difference on the Smaller Government item significant only at the 10 percent level. There are clearly substantial differences in attitudes across majors, and the differences are significant in all but one (Smaller Government) of the regressions. In two cases, however - on the items dealing with Smaller Government and Oil Prices - the inclusion of the variables for real estate equity, salary, and advanced degrees eliminated the significance of the Business major variable. Except for views on smaller government and the income distribution, Business majors differ less from General majors than Economics Majors do.

\section{III.C. Cohort Effects}

Social norms for civic behavior and attitudes on public policies may change over time, the content of economics courses changed in some areas over the decades in which our sample was attending college, and the influence of college coursework and choice of major may decay over time. ${ }^{16}$ To address those concerns, we re-estimated the regressions reported earlier with \#EconCourses interacted with the two cohort dummy variables, and with interaction terms for the time cohort dummy variables and the Economics and Business majors variables. We do not report those regressions in tables because almost none of the interaction terms were significantly different from zero. Specifically, for the regressions reported in Tables 2-4 and Table 6, only one interaction term is significant: for the Smaller Government attitude regression in Table 6, the interaction of Business with Cohort76 was positive and statistically different from zero. So this one cohort of business students was more likely to agree with this particular statement, but in

\footnotetext{
${ }^{16}$ For example, the research of Card and Krueger generated considerable debate about the youth employment effects of the minimum wage, and only our third cohort would have been exposed to this debate.
} 
general the correlation between taking economics courses, or majoring in economics, and our measures of civic behavior and attitudes on economic issues did not change across students who graduated in the three different decades.

\section{Conclusion}

Most previous studies that look at the link between education and civic behavior simply include a control for the amount of education a person has. This implies "being educated" influences a person's civic behavior, but it ignores the possibility that the content of what a person is learning might also influence behavior. Our analysis shows several statistically and economically significant associations between coursework in economics, or majoring in economics or business, and later civic behavior, including party affiliation, making donations to political parties, and volunteerism. We also find that the choice of major is a significant predictor of voting in the 2000 presidential election. Allgood et al. (forthcoming) find that the labor market decisions of business and economics majors are similar. We find a similar result for civic behavior. However, business majors are less likely than General majors to participate in time consuming activities such as voting in the 2000 Presidential election or volunteering, and when they volunteer they volunteer for fewer hours than do General majors. Economics majors instead are not less likely than General majors to engage in these behaviors. Our estimates reveal the somewhat surprising result that the attitudes of business students on public policy are more similar to General majors than to Economics majors.

It is worth emphasizing the effects we find are not just statistically significant, but they are also economically relevant. When significant, the magnitudes of the marginal effects of the choice of major variables are typically as large or larger than that of any of our control variables, except for race. 
Unfortunately, we cannot say if our results reflect what individuals have learned in these courses and majors, or if the relationships identified here are due to self-selection among college graduates into different college majors and economics course taking. Furthermore, we cannot say if those in different majors perceive the costs (value of time) or the benefits of these activities differently. But our results clearly suggest there is more to the story than simply "being educated" - so that what people study in college, or what they choose to study, is associated with their civic behaviors many years after they graduate. 


\section{References}

Acemoglu, Daron et al. "From Education to Democracy?" AER Papers and Proceedings, 95(2), May 2005, 44-49.

Aldrich, John H. "Rational Choice and Turnout." American Journal of Political Science, Vol. 37, No. 1 (Feb., 1993), pp. 246-278.

Allgood, Sam and Walstad William B. "The Longitudinal Effects of Economic Education on Teachers and Their Students." The Journal of Economic Education, Vol. 30, No. 2 (Spring, 1999), 99-111.

, Bosshardt, William, der Klaauw, Wilbert van, and Watts, Michael. "Economic Coursework and Long-Term Behavior and Experiences of College Graduates in Labor Markets and Personal Finance." Economic Inquiry, forthcoming.

Alston, R.M., Kearl, J.R., and Vaughan, M.B. "Is there a consensus among economists in the 1990s?” American Economic Review, 82(2), 1992, 203-09,

Ashenfelter, Orley and Kelley, Stanley Jr. "Determinants of Participation in Presidential Elections." Journal of Law and Economics, 18(3), Dec. 1975, 695-733.

Becker, William, William B. Walstad, and Michael Watts. "A Comparison of the Views of Economists, Economic Educators, Teachers and Journalists on Economic Issues." In An International Perspective on Economic Education, ed. W.B. Walstad. Boston, MA: Kluwer, 1994, 65-87.

Beron, Kurt. "Joint Determination of Current Classroom Performance and Additional Economics Classes: A Binary/Continuous Model." Journal of Economic Education, 1990, 21 (3): 255-64.

Blinder, Alan S., and Krueger, Alan B. "What Does the Public Know about Economic Policy, and How Does It Know It?” Brookings Papers on Economic Activity, 1, 2004, 327-87.

Brennan, Geoffrey and Hamlin, Alan Patrick. "Expressive Voting and Electoral Equilibrium." Public Choice. 95 (April 1998), 149-75.

Conover, Pamela Johnston and Feldman, Stanley. "Emotional Reactions to the Economy: I'm Mad as Hell and I'm not Going to Take it Anymore." American Journal of Political Science, Vol. 30, No. 1 (Feb., 1986), pp. 50-78

Dee, Thomas S. “Are There Civic Returns to Education?” Journal of Public Economics, 88, 2004, 1697-1720.

. "The Effects of Catholic Schooling on Civic Participation." International Tax and Public Finance, 12, 2005, 605-625. 
Freeman, Richard B. "Working for Nothing: The Supply of Volunteer Labor." Journal of Labor Economics, 15(1), 1997, S140-S166.

Frey, Bruno S. and Meier, Stephan. "Are Political Economists Selfish or Indoctrinated? Evidence From A Natural Experiment.” Economic Inquiry, 41(3), July 2003, 448-462.

Galston, William A. "Political Knolwedge, Political Engagement, and Civic Education." Annual Review of Political Science, 4, 2001, 217-234. 2003, 29-33.

Gibson, John. "Unobservable family effects and the apparent external benefits of education." Economics of Education Review, 20, 2001, 225-233.

Hayghe, Howard V. "Volunteers in the U.S.: who donates the time?" Monthly Labor Review, February 1991, 17-23.

Jamieson, Amie, Shin, Hyon B., and Day, Jennifer Day, "Voting and Registration in the Election of November 2000," Current Population Reports, P20-542, U.S. Bureau of the Census, February 2002.

Johnson, Valen E. 2003. Grade Inflation: A Crisis in College Education. New York: SpringerVerlag.

Kan, Kamhon and Yang, C.C. "On Expressive Voting: Evidence from the 1988 U.S. Presidential Election.” Public Choice, 108, 2001, 295-312.

Kleinn Daniel B. and Stern, Carlotta. 2007. "Policy Views of AEA Members," American Journal of Economics and Sociology, Blackwell Publishing, vol. 66(2), pages 309-334, 04 .

Lipset, Seymour Martin. "Some Social Requisites of Democracy: Economic Development and Political Legitimacy.” American Political Science Review, 53, 1959, 69-105.

Marwell, Gerald and Ames, Ruth E. "Economists Free Ride, Does Anyone Else?: Experiments on the Provision of Public Goods, IV." Journal of Public Economics, 15(3), June 1981, 295-310.

Matsusaka, John G. and Palda, Filip. "Voter turnout: How much can we explain?” Public Choice, 98, 1999, 431-446.

Meier, Stephan and Frey, Bruno S. "Do Business Students Make Good Citizens?” International Journal of the Economics of Business, 11(2), July 2004, 141-163. 
Milligan, Kevin, Moretti, Enrico, and Oreopoulos, Philip. "Does Education Improve Citizenship? Evidence From the U.S. and the U.K." Journal of Public Economics, 88(910), August 2004, 1667-1695.

Pew Research Center. "Fewer Voters Identify as Republicans.” March 20, 2008.

. "Evenly Divided and Increasingly Polarized: 2004 Political Landscape." November 5, 2003.

Siegfried, John J. 2009. "Trends in Economics Degrees: 1991-2008. Journal of Economic Education, 40 (3): 331-36.

Soper, John C. and William B. Walstad. "What is High School Economics? Posttest Knowledge, Attitudes, and Course Content." Journal of Economic Education 198819 (1): 37-52.

Vallaincourt, Francois. "To Volunteer or Not: Canada, 1987." Canadian Journal of Economics November 1994 27(4): 813-826

Walstad, William B. "Applying Two-Stage Least Squares." In W.E. Becker and W.B. Walstad, eds., Econometric Modeling in Economic Education Research. Norwell, MA: Kluwer Academic Press, 1987: 111-34.

and John C. Soper. "What is High School Economics? Factors Contributing to Student Achievement and Attitutdes.” Journal of Economic Education 198920 (1): 23-38. 
Table 1 - Descriptive Statistics

\begin{tabular}{|c|c|c|c|c|c|c|c|c|c|}
\hline & & $\begin{array}{r}\text { Full Sam } \\
\text { Unweighted }\end{array}$ & Weighted & \multicolumn{2}{|c|}{$\begin{array}{l}\text { Economics } \\
\text { Unweighted }\end{array}$} & \multicolumn{2}{|c|}{$\begin{array}{c}\text { Business } \\
\text { Unweighted }\end{array}$} & \multicolumn{2}{|c|}{$\begin{array}{c}\text { General } \\
\text { Unweighted }\end{array}$} \\
\hline & $\mathbf{N}$ & Mean & Mean & $\mathbf{N}$ & Mean & $\mathbf{N}$ & Mean & $\mathbf{N}$ & Mean \\
\hline No Party & 2080 & 0.2370 & 0.2440 & 259 & 0.2046 & 899 & 0.2369 & 922 & 0.2462 \\
\hline Republican & 2080 & 0.4481 & 0.3945 & 259 & 0.4981 & 899 & 0.5184 & 922 & 0.3655 \\
\hline Democrat & 2080 & 0.3087 & 0.3550 & 259 & 0.2857 & 899 & 0.2414 & 922 & 0.3807 \\
\hline OtherParty & 2080 & 0.0063 & 0.0065 & 259 & 0.0116 & 899 & 0.0033 & 922 & 0.0076 \\
\hline President & 2136 & 0.8848 & 0.9048 & 268 & 0.8918 & 918 & 0.8529 & 950 & 0.9137 \\
\hline State & 2102 & 0.7669 & 0.7900 & 265 & 0.7396 & 899 & 0.7442 & 938 & 0.7964 \\
\hline Local & 2094 & 0.6839 & 0.7132 & 264 & 0.6477 & 896 & 0.6518 & 934 & 0.7248 \\
\hline DonateMoney & 2116 & 0.3455 & 0.3424 & 267 & 0.3858 & 909 & 0.3399 & 940 & 0.3394 \\
\hline Volunteer & 2060 & 0.5748 & 0.6036 & 256 & 0.5508 & 889 & 0.5366 & 915 & 0.6186 \\
\hline Volunteer Hours & 2060 & $\begin{array}{l}2.5319 \\
(4.438)\end{array}$ & $\begin{array}{l}2.7547 \\
(4.516)\end{array}$ & 256 & $\begin{array}{l}2.0293 \\
(3.583)\end{array}$ & 889 & $\begin{array}{l}2.3285 \\
(4.490)\end{array}$ & 915 & $\begin{array}{l}2.8702 \\
(4.580)\end{array}$ \\
\hline \#EconCourses & 2159 & $\begin{array}{l}3.3682 \\
(3.050)\end{array}$ & $\begin{array}{l}1.8519 \\
(2.476)\end{array}$ & 272 & $\begin{array}{l}8.8934 \\
(2.011)\end{array}$ & 924 & $\begin{array}{l}4.0725 \\
(1.544)\end{array}$ & 963 & $\begin{array}{l}1.1319 \\
(1.823)\end{array}$ \\
\hline Economics & 2159 & 0.1260 & 0.0314 & & & & & & \\
\hline Business & 2159 & 0.4280 & 0.1485 & & & & & & \\
\hline General & 2159 & 0.4460 & 0.8201 & & & & & & \\
\hline GPA & 2149 & $\begin{array}{l}3.1014 \\
(0.496)\end{array}$ & $\begin{array}{l}3.1016 \\
(0.520)\end{array}$ & 272 & $\begin{array}{l}3.0664 \\
(0.528)\end{array}$ & 923 & $\begin{array}{l}3.1000 \\
(0.446)\end{array}$ & 954 & $\begin{array}{l}3.1128 \\
(0.531)\end{array}$ \\
\hline NormalizedGPA & 2141 & $\begin{array}{l}0.2976 \\
(0.736)\end{array}$ & $\begin{array}{l}0.3099 \\
(0.769)\end{array}$ & 272 & $\begin{array}{l}0.1699 \\
(0.679)\end{array}$ & 924 & $\begin{array}{l}0.3187 \\
(0.698)\end{array}$ & 963 & $\begin{array}{l}0.3080 \\
(0.775)\end{array}$ \\
\hline Cohort76 & 2159 & 0.3057 & 0.3242 & 272 & 0.2022 & 924 & 0.3074 & 963 & 0.3333 \\
\hline Cohort86 & 2159 & 0.3214 & 0.3436 & 272 & 0.4118 & 924 & 0.2684 & 963 & 0.3468 \\
\hline Cohort96 & 2159 & 0.3729 & 0.3322 & 272 & 0.3860 & 924 & 0.4242 & 963 & 0.3198 \\
\hline FAU & 2159 & 0.1464 & 0.1386 & 272 & 0.0625 & 924 & 0.1569 & 963 & 0.1599 \\
\hline UNL & 2159 & 0.2311 & 0.2256 & 272 & 0.1544 & 924 & 0.2695 & 963 & 0.2160 \\
\hline UNC & 2159 & 0.3877 & 0.3925 & 272 & 0.6838 & 924 & 0.3203 & 963 & 0.3686 \\
\hline Purdue & 2159 & 0.2348 & 0.2432 & 272 & 0.0993 & 924 & 0.2532 & 963 & 0.2555 \\
\hline Female & 2159 & 0.4507 & 0.5329 & 272 & 0.2426 & 924 & 0.3820 & 963 & 0.5753 \\
\hline Black & 2159 & 0.0310 & 0.0336 & 272 & 0.0331 & 924 & 0.0260 & 963 & 0.0353 \\
\hline LiveTogether & 2159 & 0.7045 & 0.7077 & 272 & 0.6985 & 924 & 0.7056 & 963 & 0.7051 \\
\hline \#Children & 2159 & $\begin{array}{l}1.0903 \\
(1.263)\end{array}$ & $\begin{array}{l}1.1101 \\
(1.241)\end{array}$ & 272 & $\begin{array}{l}0.9632 \\
(1.149)\end{array}$ & 924 & $\begin{array}{l}1.0942 \\
(1.325)\end{array}$ & 963 & $\begin{array}{l}1.1225 \\
(1.232)\end{array}$ \\
\hline Northeast & 2159 & 0.0560 & 0.0541 & 272 & 0.0919 & 924 & 0.0465 & 963 & 0.0550 \\
\hline South & 2159 & 0.5081 & 0.5047 & 272 & 0.6250 & 924 & 0.4762 & 963 & 0.5057 \\
\hline West & 2159 & 0.0750 & 0.0802 & 272 & 0.0625 & 924 & 0.0736 & 963 & 0.0800 \\
\hline Midwest & 2159 & 0.3516 & 0.3549 & 272 & 0.2022 & 924 & 0.3907 & 963 & 0.3562 \\
\hline Equity50-100 & 2159 & 0.2659 & 0.2690 & 272 & 0.2426 & 924 & 0.2662 & 963 & 0.2721 \\
\hline Equity100-250 & 2159 & 0.1978 & 0.1887 & 272 & 0.1912 & 924 & 0.2132 & 963 & 0.1848 \\
\hline Equity $>250$ & 2159 & 0.1649 & 0.1572 & 272 & 0.1949 & 924 & 0.1699 & 963 & 0.1516 \\
\hline Rent & 2159 & 0.2214 & 0.2260 & 272 & 0.2353 & 924 & 0.2143 & 963 & 0.2243 \\
\hline Salary30-50 & 2083 & 0.2616 & 0.2670 & 263 & 0.2205 & 888 & 0.2601 & 932 & 0.2747 \\
\hline Salary50-100 & 2083 & 0.3471 & 0.3306 & 263 & 0.3460 & 888 & 0.3750 & 932 & 0.3208 \\
\hline Salary $>100$ & 2083 & 0.2194 & 0.1757 & 263 & 0.3498 & 888 & 0.2511 & 932 & 0.1524 \\
\hline Bachelors & 2145 & 0.5772 & 0.5217 & 269 & 0.5316 & 921 & 0.6699 & 955 & 0.5005 \\
\hline
\end{tabular}




\begin{tabular}{l|lll|ll|ll|ll} 
MBA & 2145 & 0.1054 & 0.0627 & 269 & 0.1933 & 921 & 0.1488 & 955 & 0.0387 \\
Law & 2145 & 0.0583 & 0.0612 & 269 & 0.0967 & 921 & 0.0434 & 955 & 0.0618 \\
PhD & 2145 & 0.0308 & 0.0454 & 269 & 0.0335 & 921 & 0.0065 & 955 & 0.0534 \\
OtherDegree & 2145 & 0.2284 & 0.3089 & 269 & 0.1450 & 921 & 0.1314 & 955 & 0.3455 \\
\hline
\end{tabular}

Note: All variables but VolunteerHours, \#EconCourses, GPA, NormalizedGPA, and \#Children are $(1,0)$ dummy variables. 
Table 2 - Party Affiliation

\begin{tabular}{|c|c|c|c|c|c|c|c|}
\hline & & \multicolumn{6}{|c|}{ Multinomial Logit } \\
\hline & & No Party & No Party & Dem. & Dem. & Rep. & Rep. \\
\hline \multirow[t]{26}{*}{ Panel A } & \multirow[t]{2}{*}{ \#EconCourses } & -0.009 & -0.009 & -0.016 & -0.013 & 0.024 & 0.023 \\
\hline & & (1.97) & (1.97) & $(3.14)$ & $(2.56)$ & $(5.28)$ & $(4.58)$ \\
\hline & \multirow[t]{2}{*}{ Female } & -0.057 & -0.051 & 0.086 & 0.074 & -0.030 & -0.024 \\
\hline & & $(2.33)$ & $(1.91)$ & $(3.37)$ & $(2.71)$ & $(1.11)$ & $(0.83)$ \\
\hline & \multirow[t]{2}{*}{ Black } & 0.189 & 0.147 & 0.539 & 0.540 & -0.728 & -0.688 \\
\hline & & $(2.37)$ & (1.82) & $(5.81)$ & $(5.88)$ & $(4.95)$ & $(4.78)$ \\
\hline & \multirow[t]{2}{*}{ Cohort76 } & -0.175 & -0.165 & 0.247 & 0.285 & -0.072 & -0.120 \\
\hline & & $(4.10)$ & $(3.67)$ & $(5.88)$ & $(6.19)$ & $(1.55)$ & $(2.36)$ \\
\hline & \multirow[t]{2}{*}{ Cohort86 } & -0.099 & -0.104 & 0.103 & 0.118 & -0.004 & -0.015 \\
\hline & & $(3.35)$ & $(3.14)$ & $(2.97)$ & $(3.13)$ & $(0.10)$ & $(0.37)$ \\
\hline & \multirow[t]{2}{*}{ Northeast } & -0.081 & -0.076 & 0.077 & 0.071 & 0.004 & 0.005 \\
\hline & & $(1.31)$ & $(1.21)$ & $(1.28)$ & $(1.10)$ & $(0.06)$ & $(0.08)$ \\
\hline & \multirow[t]{2}{*}{ South } & -0.046 & -0.054 & 0 & -0.009 & 0.046 & 0.064 \\
\hline & & $(1.15)$ & $(1.34)$ & $(0.01)$ & $(0.21)$ & $(1.11)$ & $(1.54)$ \\
\hline & \multirow[t]{2}{*}{ West } & -0.025 & -0.013 & 0.111 & 0.094 & -0.086 & -0.082 \\
\hline & & $(0.52)$ & $(0.25)$ & $(2.18)$ & $(1.81)$ & (1.63) & (1.48) \\
\hline & \multirow[t]{2}{*}{ LiveTogether } & -0.040 & -0.037 & 0.002 & 0.024 & 0.037 & 0.014 \\
\hline & & (1.47) & $(1.30)$ & $(0.08)$ & $(0.75)$ & (1.13) & $(0.40)$ \\
\hline & \multirow[t]{2}{*}{ \#Children } & -0.029 & -0.026 & -0.032 & -0.024 & 0.061 & 0.050 \\
\hline & & $(2.41)$ & $(2.11)$ & $(2.51)$ & (1.89) & $(4.90)$ & $(4.00)$ \\
\hline & \multirow{2}{*}{ NormalizedGPA } & 0.008 & -0.009 & -0.022 & -0.029 & 0.014 & 0.038 \\
\hline & & $(0.43)$ & $(0.45)$ & $(0.97)$ & $(1.19)$ & $(0.61)$ & (1.61) \\
\hline & \multirow{4}{*}{$\begin{array}{l}\text { School Indicators } \\
\text { Advanced Degrees } \\
\text { Rent and Equity } \\
\text { Salary }\end{array}$} & Yes & Yes & Yes & Yes & Yes & Yes \\
\hline & & No & Yes & No & Yes & No & Yes \\
\hline & & No & Yes & No & Yes & No & Yes \\
\hline & & No & Yes & No & Yes & No & Yes \\
\hline \multirow[t]{9}{*}{ Panel B } & \multirow[t]{2}{*}{ Economics } & -0.047 & -0.056 & -0.083 & -0.047 & 0.123 & 0.100 \\
\hline & & $(2.03)$ & $(2.29)$ & $(2.43)$ & $(1.33)$ & $(3.22)$ & $(2.48)$ \\
\hline & \multirow[t]{2}{*}{ Business } & -0.022 & -0.027 & -0.109 & -0.079 & 0.121 & 0.096 \\
\hline & & $(1.16)$ & $(1.24)$ & $(4.74)$ & $(3.19)$ & (4.99) & $(3.61)$ \\
\hline & \multirow{2}{*}{\multicolumn{3}{|c|}{ Econ. - Bus. $=0^{\S}$}} & 0.76 & 1.28 & 0.24 & 0.41 \\
\hline & & & & $(0.38)$ & $(0.26)$ & $(0.62)$ & $(0.52)$ \\
\hline & \multirow[t]{2}{*}{ Econ. $=$ Bus. $=0^{\S \S}$} & & & 4.01 & 1.62 & 10.65 & 7.62 \\
\hline & & & & $(0.13)$ & $(0.44)$ & $(0.00)$ & $(0.02)$ \\
\hline & Obs. & 2067 & 2008 & 2067 & 2008 & 2067 & 2008 \\
\hline
\end{tabular}

Note: Marginal effects of multinomial logit and probit with robust z-statistics in parenthesis. Advanced degrees is a set of four dummy variables: MBA, Law, $\mathrm{PhD}$, and OtherDegree. Rent and Equity is the dummy variable Rent and three dummy variables for different values of the value of equity. Salary is three different dummy variables for different values of annual salary.

${ }^{\S} \chi^{2}(1)$ statistics with p-value in parentheses.

${ }^{8} \chi^{2}(2)$ statistics with p-value in parentheses. 
Table 3 - Voting Behavior

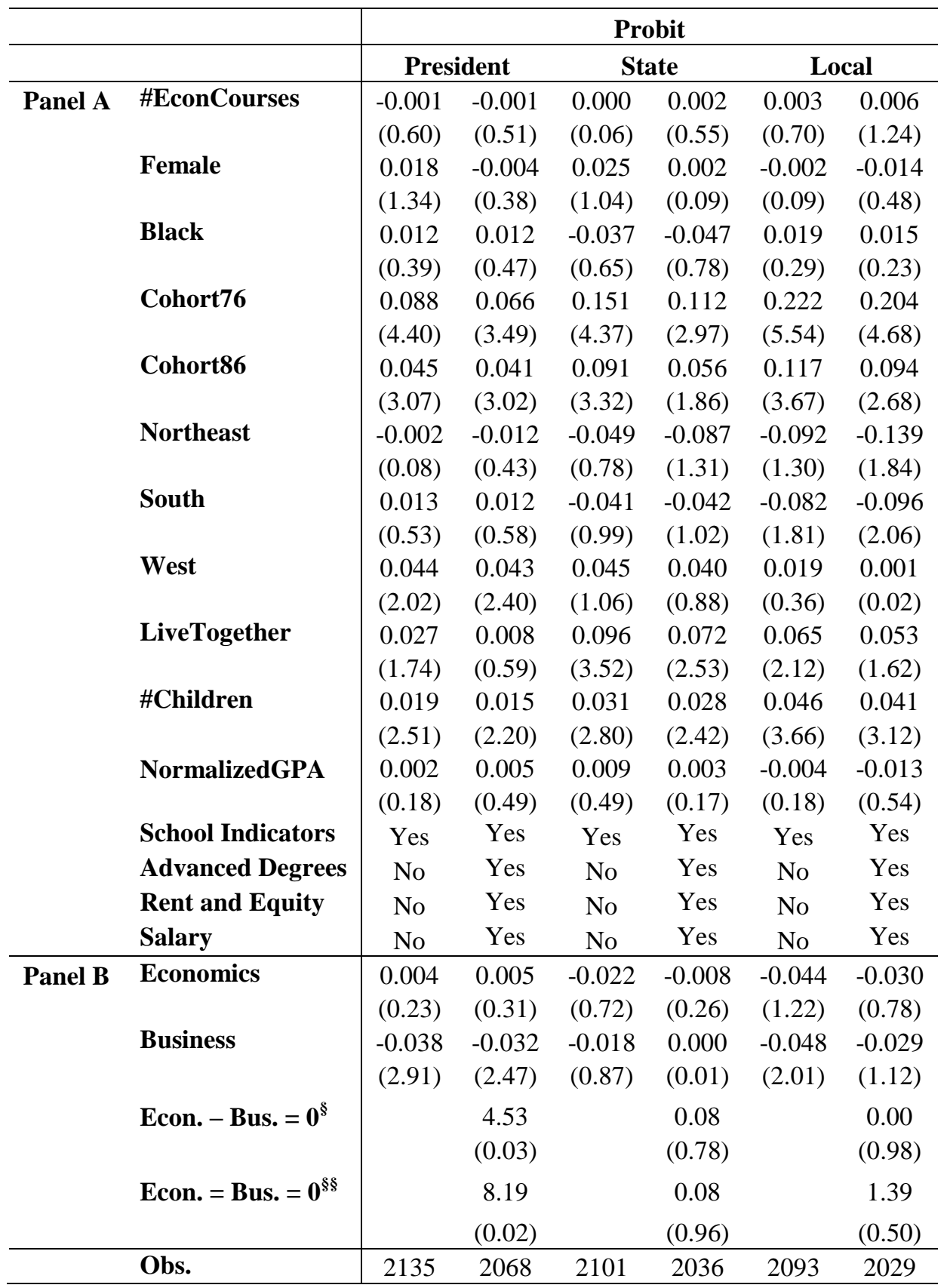

Note: Marginal effects of multinomial logit and probit with robust $z$-statistics in parenthesis. Advanced degrees is a set of four dummy variables: MBA, Law, $\mathrm{PhD}$, and OtherDegree. Rent and Equity is the dummy variable Rent and three dummy variables for different values of the value of equity. Salary is three different dummy variables for different values of annual salary.

${ }^{\S} \chi^{2}(1)$ statistics with p-value in parentheses.

${ }^{8} \chi^{2}(2)$ statistics with $p$-value in parentheses. 
Table 4 - Giving: Time and Money

\begin{tabular}{|c|c|c|c|c|c|c|c|}
\hline \multirow{3}{*}{ Panel A } & \multirow[b]{2}{*}{ \#EconCourses } & \multicolumn{2}{|c|}{ DonateMoney } & \multicolumn{2}{|c|}{ Volunteer } & \multicolumn{2}{|c|}{ Volunteer Hours } \\
\hline & & 0.015 & 0.010 & 0.006 & 0.003 & -0.015 & -0.035 \\
\hline & & $(3.10)$ & $(1.83)$ & (1.07) & $(0.52)$ & $(0.48)$ & (1.07) \\
\hline & \multirow[t]{2}{*}{ Female } & -0.070 & -0.054 & 0.091 & 0.093 & 0.916 & 0.826 \\
\hline & & $(2.44)$ & $(1.72)$ & $(3.01)$ & (2.89) & $(4.83)$ & $(4.03)$ \\
\hline & \multirow[t]{2}{*}{ Black } & -0.007 & 0.023 & 0.066 & 0.077 & 1.387 & 1.439 \\
\hline & & $(0.09)$ & $(0.27)$ & $(0.80)$ & $(0.94)$ & (2.68) & $(2.80)$ \\
\hline & \multirow[t]{2}{*}{ Cohort76 } & 0.438 & 0.427 & 0.220 & 0.175 & 2.016 & 1.677 \\
\hline & & $(9.01)$ & $(7.87)$ & $(4.76)$ & $(3.41)$ & (6.44) & $(4.90)$ \\
\hline & \multirow[t]{2}{*}{ Cohort86 } & 0.236 & 0.224 & 0.085 & 0.053 & 0.802 & 0.672 \\
\hline & & $(5.91)$ & $(5.12)$ & $(2.27)$ & $(1.29)$ & $(3.22)$ & $(2.49)$ \\
\hline & \multirow[t]{2}{*}{ Northeast } & 0.022 & -0.009 & -0.088 & -0.086 & -0.312 & -0.319 \\
\hline & & $(0.32)$ & $(0.13)$ & $(1.20)$ & $(1.11)$ & $(0.71)$ & $(0.71)$ \\
\hline & \multirow[t]{2}{*}{ South } & -0.039 & -0.051 & -0.053 & -0.064 & -0.303 & -0.324 \\
\hline & & $(0.89)$ & $(1.11)$ & (1.14) & $(1.33)$ & $(1.05)$ & (1.10) \\
\hline & \multirow[t]{2}{*}{ West } & -0.009 & -0.009 & -0.100 & -0.120 & -0.639 & -0.705 \\
\hline & & $(0.16)$ & $(0.17)$ & $(1.72)$ & (1.99) & (1.73) & $(1.86)$ \\
\hline & \multirow[t]{2}{*}{ LiveTogether } & 0.038 & 0.017 & -0.033 & -0.065 & -0.231 & -0.453 \\
\hline & & (1.14) & $(0.48)$ & $(0.95)$ & $(1.75)$ & $(1.03)$ & (1.89) \\
\hline & \multirow[t]{2}{*}{ \#Children } & 0.010 & 0.006 & 0.057 & 0.050 & 0.403 & 0.350 \\
\hline & & $(0.83)$ & $(0.45)$ & $(3.98)$ & $(3.41)$ & (4.69) & $(3.99)$ \\
\hline & \multirow[t]{2}{*}{ NormalizedGPA } & -0.024 & -0.046 & 0.014 & 0.020 & -0.192 & -0.169 \\
\hline & & $(0.99)$ & $(1.78)$ & $(0.58)$ & $(0.76)$ & $(1.20)$ & $(1.00)$ \\
\hline & \multirow{4}{*}{$\begin{array}{l}\text { School Indicators } \\
\text { Advanced Degrees } \\
\text { Rent and Equity } \\
\text { Salary }\end{array}$} & Yes & Yes & Yes & Yes & Yes & Yes \\
\hline & & No & Yes & No & Yes & No & Yes \\
\hline & & No & Yes & No & Yes & No & Yes \\
\hline & & No & Yes & No & Yes & No & Yes \\
\hline \multirow[t]{9}{*}{ Panel B } & \multirow[t]{2}{*}{ Economics } & 0.029 & 0.021 & -0.022 & -0.059 & -0.412 & -0.676 \\
\hline & & $(0.74)$ & $(0.48)$ & $(0.55)$ & $(1.35)$ & $(0.79)$ & $(1.24)$ \\
\hline & \multirow[t]{2}{*}{ Business } & 0.013 & -0.006 & -0.060 & -0.082 & -0.701 & -0.915 \\
\hline & & $(0.51)$ & $(0.20)$ & $(2.30)$ & $(2.86)$ & $(2.07)$ & $(2.50)$ \\
\hline & \multirow[t]{2}{*}{ Econ. - Bus. $=0^{\S}$} & & 0.40 & & 0.29 & & 0.20 \\
\hline & & & $(0.53)$ & & $(0.59)$ & & $(0.65)$ \\
\hline & \multirow[t]{2}{*}{ Econ. $=$ Bus. $=0^{\S \S}$} & & 0.40 & & 8.30 & & 3.17 \\
\hline & & & $(0.82)$ & & $(0.02)$ & & $(0.04)$ \\
\hline & Obs. & 2115 & 2049 & 2059 & 2001 & 2059 & 2001 \\
\hline
\end{tabular}

Note: DonateMoney and Volunteer are probit regressions, and VolunteerHours is a tobit. Marginal effects with robust z-statistics in parenthesis. Advanced degrees is a set of four dummy variables: MBA, Law, PhD, and OtherDegree. Rent and Equity is the dummy variable Rent and three dummy variables for different values of the value of equity. Salary is three different dummy variables for different values of annual salary.

${ }^{\S} \chi^{2}(1)$ statistics with p-value in parentheses.

${ }^{8 s} \chi^{2}(2)$ statistics with $p$-value in parentheses. 
Table 5 - Attitudes by Major

\begin{tabular}{|c|c|c|c|c|c|c|c|}
\hline & & \multicolumn{2}{|c|}{ Full Sample } & \multirow[t]{2}{*}{ Economics } & \multirow[t]{2}{*}{ Business } & \multirow[t]{2}{*}{ General } & \multirow[t]{2}{*}{ Economists ${ }^{*}$} \\
\hline & & Weighted & Unweighted & & & & \\
\hline \multirow[t]{3}{*}{$\begin{array}{l}\text { Tariffs and import quotas usually reduce general } \\
\text { economic welfare. (Tariffs) }\end{array}$} & Agree & 43 & 38 & 59 & 45 & 36 & 71.3 \\
\hline & Gen Agree & 35 & 36 & 28 & 33 & 38 & 21.3 \\
\hline & Disagree & 23 & 25 & 12 & 22 & 27 & 6.5 \\
\hline \multirow[t]{3}{*}{$\begin{array}{l}\text { A large federal budget deficit has an adverse effect } \\
\text { on the economy. (Government Deficit) }\end{array}$} & Agree & 53 & 57 & 42 & 50 & 59 & 35.1 \\
\hline & Gen Agree & 30 & 28 & 39 & 31 & 27 & 47.6 \\
\hline & Disagree & 17 & 15 & 19 & 19 & 14 & 15.7 \\
\hline \multirow[t]{3}{*}{$\begin{array}{l}\text { The distribution of income in the U.S. should be } \\
\text { more equal. (Distribution) }\end{array}$} & Agree & 30 & 35 & 22 & 23 & 38 & 48.5 \\
\hline & Gen Agree & 23 & 23 & 26 & 21 & 24 & 24.4 \\
\hline & Disagree & 48 & 41 & 52 & 56 & 38 & 26.7 \\
\hline \multirow{3}{*}{$\begin{array}{l}\text { The level of government relative to national income } \\
\text { (GDP) spending should be reduced. } \\
\text { (Smaller Government) }\end{array}$} & Agree & 49 & 50 & 46 & 50 & 50 & 35.6 \\
\hline & Gen Agree & 33 & 32 & 34 & 34 & 32 & 19 \\
\hline & Disagree & 18 & 18 & 21 & 16 & 19 & 44.6 \\
\hline \multirow[t]{3}{*}{$\begin{array}{l}\text { A large balance of trade deficit has an adverse effect } \\
\text { on the economy. (Trade Deficit) }\end{array}$} & Agree & 52 & 55 & 38 & 52 & 57 & 26.3 \\
\hline & Gen Agree & 33 & 33 & 36 & 32 & 33 & 37.3 \\
\hline & Disagree & 15 & 12 & 26 & 16 & 10 & 26.3 \\
\hline \multirow[t]{3}{*}{$\begin{array}{l}\text { If a cartel reduces the amount of oil available for the } \\
\text { United States to import, the U.S. should not allow } \\
\text { gasoline prices to rise more than } 10 \% \text {. (Oil Prices) }\end{array}$} & Agree & 21 & 24 & 10 & 19 & 26 & \\
\hline & Gen Agree & 19 & 20 & 10 & 19 & 20 & \\
\hline & Disagree & 60 & 56 & 81 & 61 & 53 & \\
\hline \multirow{3}{*}{$\begin{array}{l}\text { Raising the minimum wage by } 10 \% \text { would sharply } \\
\text { increase unemployment rate for teenagers and other } \\
\text { workers who currently receive low wages. } \\
\text { (Minimum Wage) }\end{array}$} & Agree & 24 & 22 & 31 & 25 & 21 & 56.5 \\
\hline & Gen Agree & 22 & 20 & 24 & 23 & 20 & 22.4 \\
\hline & Disagree & 55 & 57 & 45 & 52 & 59 & 20.5 \\
\hline
\end{tabular}


Note: Table gives percentages. *Numbers for economists are taken from Alston et al. (1992). 
Table 6: Attitudes

\begin{tabular}{|c|c|c|c|c|c|c|c|c|c|c|c|c|c|c|c|}
\hline \multirow{3}{*}{ Panel A } & \multirow{3}{*}{ \#EconCourses } & \multicolumn{2}{|c|}{ Tarrifs } & \multicolumn{2}{|c|}{$\begin{array}{l}\text { Trade } \\
\text { Deficit }\end{array}$} & \multicolumn{2}{|c|}{$\begin{array}{c}\text { Government } \\
\text { Deficit }\end{array}$} & \multicolumn{2}{|c|}{$\begin{array}{c}\text { Smaller } \\
\text { Government }\end{array}$} & \multicolumn{2}{|c|}{$\begin{array}{c}\text { Oil } \\
\text { Prices }\end{array}$} & \multicolumn{2}{|c|}{$\begin{array}{c}\text { Minimum } \\
\text { Wage }\end{array}$} & \multicolumn{2}{|c|}{ Distribution } \\
\hline & & 0.018 & 0.018 & -0.012 & -0.012 & -0.001 & -0.002 & 0.001 & -0.001 & -0.034 & -0.035 & 0.012 & 0.012 & -0.03 & -0.026 \\
\hline & & $(3.75)$ & $(3.57)$ & $(4.10)$ & $(3.87)$ & $(0.17)$ & $(0.62)$ & $(0.23)$ & $(0.17)$ & $(6.07)$ & $(5.72)$ & $(2.24)$ & $(2.26)$ & $(5.76)$ & (4.64) \\
\hline & \multirow[t]{2}{*}{ Female } & -0.087 & -0.088 & 0.016 & 0.012 & 0.036 & 0.042 & 0.027 & 0.024 & 0.133 & 0.122 & -0.049 & -0.039 & 0.077 & 0.058 \\
\hline & & (3.27) & $(3.01)$ & $(0.84)$ & $(0.61)$ & $(1.73)$ & (1.89) & $(1.15)$ & $(0.94)$ & $(4.27)$ & (3.61) & $(1.63)$ & (1.19) & (2.59) & (1.78) \\
\hline & \multirow[t]{2}{*}{ Black } & -0.031 & -0.006 & 0.033 & 0.026 & 0.084 & 0.116 & 0.08 & 0.11 & 0.228 & 0.223 & 0.073 & 0.096 & 0.304 & 0.292 \\
\hline & & $(0.42)$ & $(0.07)$ & $(0.63)$ & $(0.46)$ & $(1.35)$ & (1.97) & $(1.26)$ & (1.94) & $(2.42)$ & $(2.24)$ & $(0.88)$ & (1.13) & (3.73) & (3.64) \\
\hline & \multirow[t]{2}{*}{ Cohort76 } & 0.043 & 0.04 & 0.08 & 0.093 & 0.06 & 0.062 & 0.011 & 0.015 & -0.051 & 0.002 & 0.027 & 0.041 & 0.002 & 0.079 \\
\hline & & $(1.00)$ & $(0.85)$ & $(2.79)$ & $(2.90)$ & $(1.82)$ & $(1.72)$ & $(0.30)$ & $(0.36)$ & $(1.00)$ & $(0.03)$ & $(0.56)$ & $(0.75)$ & $(0.05)$ & (1.46) \\
\hline & \multirow[t]{2}{*}{ Cohort86 } & 0.015 & 0.023 & 0.052 & 0.063 & 0.02 & 0.027 & 0.03 & 0.046 & -0.101 & -0.047 & 0.018 & 0.018 & -0.009 & 0.041 \\
\hline & & $(0.43)$ & $(0.61)$ & (2.39) & $(2.68)$ & $(0.77)$ & $(0.98)$ & $(0.99)$ & (1.39) & $(2.52)$ & $(1.07)$ & $(0.46)$ & $(0.42)$ & $(0.24)$ & $(0.95)$ \\
\hline & \multirow[t]{2}{*}{ Northeast } & -0.021 & -0.04 & -0.035 & -0.031 & 0.012 & 0.015 & -0.029 & -0.037 & -0.158 & -0.156 & 0.028 & 0.031 & 0.049 & 0.073 \\
\hline & & $(0.32)$ & $(0.56)$ & $(0.77)$ & $(0.68)$ & $(0.25)$ & $(0.32)$ & $(0.53)$ & $(0.62)$ & $(2.12)$ & (2.04) & $(0.39)$ & $(0.42)$ & (0.69) & $(1.00)$ \\
\hline & \multirow[t]{2}{*}{ South } & -0.024 & -0.023 & 0.042 & 0.04 & 0.039 & 0.023 & -0.005 & -0.003 & -0.054 & -0.063 & -0.007 & 0.01 & -0.028 & -0.023 \\
\hline & & $(0.57)$ & $(0.53)$ & $(1.46)$ & $(1.32)$ & (1.09) & $(0.65)$ & $(0.13)$ & $(0.08)$ & $(1.10)$ & $(1.24)$ & $(0.15)$ & $(0.20)$ & $(0.60)$ & $(0.45)$ \\
\hline & \multirow[t]{2}{*}{ West } & 0.052 & 0.055 & 0.001 & 0.003 & 0.061 & 0.053 & -0.037 & -0.029 & -0.156 & -0.162 & -0.107 & -0.079 & 0.018 & 0.049 \\
\hline & & $(1.03)$ & $(1.06)$ & $(0.01)$ & $(0.08)$ & (1.64) & $(1.42)$ & $(0.80)$ & $(0.62)$ & $(2.68)$ & $(2.71)$ & $(1.90)$ & $(1.36)$ & $(0.30)$ & $(0.80)$ \\
\hline & \multirow[t]{2}{*}{ LiveTogether } & 0.014 & 0.001 & -0.013 & -0.008 & 0.021 & 0.026 & 0.006 & 0.01 & -0.113 & -0.096 & 0.015 & 0.006 & -0.02 & 0.013 \\
\hline & & $(0.45)$ & $(0.02)$ & $(0.58)$ & $(0.34)$ & $(0.82)$ & $(0.97)$ & $(0.21)$ & $(0.35)$ & $(3.12)$ & $(2.47)$ & $(0.43)$ & $(0.15)$ & $(0.58)$ & $(0.36)$ \\
\hline & \multirow[t]{2}{*}{ \#Children } & 0.008 & 0.015 & -0.006 & -0.007 & 0.003 & 0.005 & 0.023 & 0.023 & 0.004 & 0.008 & 0.009 & 0.009 & -0.057 & -0.047 \\
\hline & & $(0.65)$ & $(1.18)$ & $(0.69)$ & $(0.86)$ & $(0.32)$ & $(0.53)$ & $(1.98)$ & (1.97) & $(0.31)$ & $(0.55)$ & $(0.70)$ & $(0.64)$ & (4.11) & (3.36) \\
\hline & \multirow[t]{2}{*}{ NormalizedGPA } & -0.001 & -0.011 & -0.023 & -0.019 & -0.007 & -0.007 & -0.071 & -0.063 & -0.163 & -0.15 & -0.051 & -0.045 & 0.033 & 0.044 \\
\hline & & $(0.03)$ & $(0.49)$ & $(1.54)$ & (1.18) & $(0.42)$ & $(0.39)$ & $(3.37)$ & $(2.87)$ & $(6.07)$ & (5.27) & $(2.09)$ & $(1.74)$ & (1.34) & (1.65) \\
\hline & Schoo & Yes & Yes & Yes & Yes & Yes & Yes & Yes & Yes & Yes & Yes & Yes & Yes & Yes & Yes \\
\hline & Advanced Degrees & No & Yes & No & Yes & No & Yes & No & Yes & No & Yes & No & Yes & No & Yes \\
\hline & Rent and Equity & No & Yes & No & Yes & No & Yes & No & Yes & No & Yes & No & Yes & No & Yes \\
\hline & Salary & No & Yes & No & Yes & No & Yes & No & Yes & No & Yes & No & Yes & No & Yes \\
\hline \multirow[t]{9}{*}{ Panel B } & \multirow[t]{2}{*}{ Economics } & 0.112 & 0.101 & -0.176 & -0.173 & -0.028 & -0.045 & -0.005 & -0.017 & -0.261 & -0.25 & 0.118 & 0.109 & -0.142 & -0.107 \\
\hline & & $(3,19)$ & $(2.65)$ & $(5.65)$ & $(5.22)$ & $(0.99)$ & $(145)$ & $(0.16)$ & $(0.52)$ & $(6.74)$ & $(6.00)$ & $(2.90)$ & $(2.50)$ & (3.47) & $(2.43)$ \\
\hline & \multirow[t]{2}{*}{ Business } & 0.03 & 0.017 & -0.062 & -0.069 & -0.043 & -0.05 & 0.044 & 0.034 & -0.062 & -0.051 & 0.062 & 0.054 & -0.189 & -0.158 \\
\hline & & $(1.32)$ & $(0.69)$ & $(3.57)$ & $(3.57)$ & $(2.26)$ & $(2.37)$ & $(2.30)$ & $(1.53)$ & $(2.29)$ & $(1.67)$ & $(2.37)$ & $(1.85)$ & (7.19) & $(5.37)$ \\
\hline & \multirow[t]{2}{*}{ Econ. - Bus. $=0^{\S}$} & & 5.10 & & 7.91 & & 0.04 & & 2.73 & & 25.44 & & 1.70 & & 1.51 \\
\hline & & & $(0.02)$ & & $(0.00)$ & & $(0.84)$ & & $(0.10$ & & $(0.0$ & & $(0.19)$ & & $(0.22)$ \\
\hline & Econ. $=$ Bus. $=0^{\S \S}$ & & 7.03 & & 29.39 & & 5.90 & & 3.80 & & 36.26 & & 7.15 & & 28.94 \\
\hline & & & $(0.03)$ & & $(0.00)$ & & $(0.05)$ & & $(0.15)$ & & $(0.00)$ & & $(0.03)$ & & $(0.00)$ \\
\hline & Obs & 1951 & 1888 & 1980 & 1912 & 2053 & 1981 & 2000 & 1928 & 2024 & 1958 & 2034 & 1961 & 2066 & 1993 \\
\hline
\end{tabular}


Note: Dependent variable for each probit regression is equal to one if person agreed or generally agreed with statement. Marginal effects of probit with robust zstatistics in parenthesis. Advanced degrees is a set of four dummy variables: MBA, Law, PhD, and OtherDegree. Rent and Equity is the dummy variable Rent and three dummy variables for different values of the value of equity. Salary is three different dummy variables for different values of annual salary.

${ }^{8} \chi^{2}(1)$ statistics with p-value in parentheses.

${ }^{8} \chi^{2}(2)$ statistics with p-value in parentheses. 